\title{
Dentistry and Veterinary Medicine a Necessary Dialogue to Expand the Possibilities of Action
}

\author{
Caribé Carolina, Poubel Déborah LN*, Krully Paula and Macedo SB \\ Department of Dentistry, School of Health Sciences, Brasília
}

*Corresponding author: Déborah Lousan do Nascimento Poubel, Department of Dentistry, School of Health Sciences, Brasília

\begin{tabular}{|c|c|}
\hline ARTICLE INFO & ABSTRACT \\
\hline & \multirow{4}{*}{$\begin{array}{l}\text { Dentistry holds a prominent place among the specializations of veterinary medicine. } \\
\text { However, regarding the dentofacial study of animals, it is clear that knowledge is limited } \\
\text { whitin the curriculum offered to graduate students in the area. From information provid- } \\
\text { ed by the Ministry of Education (e.mec), there are } 264 \text { universities and public schools in } \\
\text { Brazil, but only } 48 \text { provide the course of Veterinary. Of these, only } 8.33 \% \text { offer the disci- } \\
\text { pline of veterinary dentistry, as an optional course, and none of them offers the subject } \\
\text { as a compulsory part of the training. Besides that, in accordance with current legislation, } \\
\text { there is a performance constraint preventing and rehabilitating treatment of animals, } \\
\text { allowing only veterinarians to exercise this specialty. In spite of that, in most cases, these } \\
\text { professionals do not have the access to that instruction during the graduation. Given this } \\
\text { reality, it is relevant to propose a debate on the importance of improving integration be- } \\
\text { tween Veterinary Medicine and Dentistry department, signaling pathways for the forma- } \\
\text { tion of multidisciplinary professionals, allowing to expand the possibilities for action and } \\
\text { strengthening the dialogue between areas; aimed at improving the quality of care. }\end{array}$} \\
\hline Published: March 21, 2019 & \\
\hline $\begin{array}{l}\text { Citation: Caribé Carolina, Poubel Déb- } \\
\text { orah LN, Krully Paula and Macedo SB. } \\
\text { Dentistry and Veterinary Medicine a } \\
\text { Necessary Dialogue to Expand the Pos- } \\
\text { sibilities of Action. Biomed J Sci \& Tech } \\
\text { Res 16(2)-2019. BJSTR. MS.ID.002825. }\end{array}$ & \\
\hline $\begin{array}{l}\text { Keywords: Dentistry; Veterinary Med- } \\
\text { cine; Interdisciplinary Studies; Oral } \\
\text { Health }\end{array}$ & \\
\hline
\end{tabular}

\section{Introduction}

The practice of oral health has evolved into a broad profession with a wide reach making dentistry become a single network, woven based on research, technological advances and influences from other professions. Each segment, within its occupations, can be mutually benefited with a multidisciplinary; which meets the wellknown growth and development of dentistry in the animal field [1]. As Dentistry is the science that studies oral health, its pathologies and its treatments, a search has begun on how dental procedures would be performed within the veterinary field and in which ways they resemble and differ from human dentistry. Veterinary medicine has advanced a lot in the last fifteen years, branching into several specialties, among which dentistry stands out [2]. Damage to the oral health of an animal can lead to lighter problems such as discomfort and pain or problems of considerable severity, such as weakness, decreased intake of water and food, systemic alterations and, ultimately, death of the animal [2]. Among the oral conditions found are periodontal diseases, which is the most frequent disease, followed by fracture and/or dental traumatism, with or without pulpal exposure [2-7].
The prevention of oral diseases maintains the efficiency of the digestive mechanisms, which directly affects the quality of life of the animal, increases its reproductive efficiency and its life expectancy [8]. With this thought, the question about the teaching of Veterinary Dentistry, its means and forms of action in Brazil and the reason for having little or no integration with the dental surgeon in this field of action has emerged. This work seeks to compare veterinary and human dentistry, dealing with the most common intercurrences. In addition, it raises the debate based on regulatory frameworks and academic production, the need to rethink the insertion of the discipline of dentistry as a compulsory or optional part in the courses of veterinary medicine, demonstrating the importance of a dialogue between Veterinary and Dentistry and motivating the discussion about the formation of an interdisciplinary team in treatment units. Therefore, the objective is to discuss the historical and intersectional aspects between veterinary dentistry and human dentistry and to discuss the importance of the interrelationship between both, showing the need for a partnership between veterinarians and dentists, with the aim of contributing to the improvement of the quality of care. 


\section{Materials and Methods}

This study was carried out through a bibliographical review with the objective to learn from the perspective of some authors about Veterinary Dentistry, its means of action and the participation of the dental surgeon in this process, since the veterinary legislation currently in force in Brazil prevents the dentist of an in loco performance. The preparation of this review was based on material already published on the subject: books, scientific articles, periodicals, master's dissertations and materials available on the Internet in the following databases: PUBMED, DEDALUS, SCOPUS and the Ministry of Education. The selection of the materials for the bibliographic analysis initiated from the establishment of inclusion and exclusion criteria. The inclusion criterion was based on the definition of key words: dentistry, veterinary medicine, dentofacial, veterinary dentistry, interdisciplinary studies, integration, periodontics, dental trauma, endodontics, oral health, retrospective studies and their counterparts in English. Articles published in a foreign language other than the English language were excluded. No article was excluded using the date of publication as criteria.

The search for the articles took place in the library of the Faculty of Veterinary Medicine of the University Campus of the University of São Paulo (USP, Brazil) and in the library of the University of Brasília (UnB, Brazil).

The website of the Ministry of Education was visited in order to use the e.mec system. This access had the objective of obtaining the information about the public higher education institutions that exist in Brazil and the amount of courses of veterinary medicine available. After this stage, the 48 courses of veterinary medicine had their disciplinary grades analyzed to understand how many offer the discipline of dentistry as a compulsory or optional part of the training and in how many present an oral health aspect throughout the text of its curricular guidelines. After the bibliographical survey, the material found was organized in order to search for parallels between them and, consequently, to make possible comparatives.

\section{Literature Review}

The issues that will be addressed in this literature revision are the history of veterinary dentistry, the legislation in force in Brazil, the teaching of dentistry within the courses of veterinary medicine, the main oral diseases found in animals of various species and their means of treatment, creating a comparative of techniques with human dentistry.

\section{History}

The theme in this study dates from $3500 \mathrm{BC}$ to the current historical moment. There is evidence that in China, from at least $600 \mathrm{BC}$, the age of horses was already estimated by examination of the teeth [9]. In $1135 \mathrm{AD}$, a more complete description occurred in a manuscript that also mentioned procedures such as acupuncture and the relationship of the teeth to the internal organs of animals [9]. The horse was the central object of the beginning of veterinary dentistry because of its great importance for transportation, military use, sports and its mechanical potential [9]. These historical facts show how the interest and curiosity for the dentition of non-human animals is as old as the very emergence of Dentistry and Veterinary Medicine itself. The Dental Art, as Dentistry was known, appeared in Prehistory, but has its earliest records in 3500 BCE in Mesopotamia [10]. Since ancient Babylon at the time of the Hammurabi Code in about 2200 BCE, it was already known the fees that veterinarians charged on their procedures and the carrying out of dental extractions of the animals by the barbarians.

In Ancient Greece, several important veterinary manuscripts were produced, such as in VETERINARIUS es, et equi Inspection (The Veterinary Art, Horse Inspection) written by Simon in Athens dated $430 \mathrm{BC}$ which already included a careful description of the process of eruption of the teeth and of the estimation of the age of the horse by the analysis of the dental arcade [9]. Next, Aristotle wrote his work História Animalium (333 BC), which portrayed a little about periodontal disease in horses [9]. In 350 BC, Pelagonius wrote a treatise on equine medicine in which he assigned a chapter dealing only with the dentition, called De Dentibus [11]. In about 400 AD, Chiron, a Roman writer, wrote an extensive manuscript that discussed various aspects of equine dentistry, such as mandible tumors, dental diseases, procedure techniques in cases of mandibular fracture and a description of the dentition [9]. In around $500 \mathrm{AD}$, the greatest contribution of the Roman era to the veterinary emerged, when Vegetius wrote In VETERINARIUS Art (The Art of Veterinary Medicine), which brought important information such as the use of splints for fixing the jaw in case of fracture and a thousand years later, in 1558, this became the first printed book of Veterinary Medicine [9].

Written around AD 580, the work of Ippocras was translated into Greek and Arabic in the $9^{\text {th }}$ century and its manuscript was available in Latin around 14009. The work brought issues such as defects and problems caused by the bite and also a specific surgery for the cutting or extraction of canines and lateral incisors to better accommodate the bite [9]. The onset of dental or oral surgical procedures that were described for dogs occurred without anesthesia and were often indicated on the basis of superstitions, rarely with a medical reason, such as removal of the most rostral end of the tongue with the justification of preventing rabies [9]. In the Middle Ages, around 950 AD, a manuscript entitled Hippiatrika was written by the Emperor Constantine VII. It was a compilation of all manuscripts written in Greek and Latin on the most varied subjects of veterinary medicine, including dentistry [9]. In an interval of approximately 1000 years, there was little advance since the published materials were all copies or compilations of the Greek and Roman material and sometimes with outdated content [9]. In 1762, the first school of veterinary medicine was established in Lyon, France and dentistry was largely peripheral in the first 200 years [9]. 
Until the nineteenth century, dental procedures were carried out by the owners of the animals themselves or by heifers and trainers [9]. It was only in the twentieth century that Erwin Becker, in 1930, revolutionized the means of dental correction in equines when he used a rotating disc system, electrically driven with incorporation of a continuous irrigation for cooling teeth [11]. In the 1970s, the United States and Europe lived an evolution in the dental techniques applied to domestic animals and in 1977 the American Veterinary Dental Society (AVDS) was founded. In 1982, the first book restricted to the subject was Tierärztliche Zahnheilkunde (Veterinary Dentistry) [11] and in the 1990s this specialty began to be developed in Brazil [11]. Professor, dentist and veterinarian, Antônio Gioso was one of the forerunners of veterinary dentistry in Brazil, publishing the first original book on veterinary dentistry in Portuguese in 2007, titled: Veterinary Dentistry for the Clinician of Small Animals [12], which opened the doors for other prominent names. With the growth of the specialty, Veterinary Medicine professionals began to worry about the inclusion of specialists other than veterinarians working in the area, raising questions such as technical and legal qualifications [11]. The Federal

Council of Veterinary Medicine (CFMV) also began to raise interest in the subject and in 1995, at its II National Symposium, held a lecture on veterinary dentistry, highlighting it as an emerging specialty of great relevance [11]. At that moment, a change of perspective occurred because the congresses of the Brazilian Society of Zoos (SZB) began to present works by dentists associated with veterinarians [11]. As a result of this, since 1996, some zoos have equipment and professionals to practice veterinary dentistry [11]. An important issue to be raised in the light of the presented history is that this movement to raise the awareness of the importance of dentistry to veterinarians was a technical-scientific matter, but it seems to be based on a marketing concern.

\section{Brazilian Legislation and the Teaching of Dentistry in Veterinary Medicine Courses}

The existence of a culture in health areas that little stimulates the movement of exchanges between the specialties is notorious in Brazil. In this sense, and in order to reflect on the individualized exercise within each profession, this topic of work addresses the current legislation that underpins this prerogative of an exclusivist service. Regarding the profession of the Veterinarian, Federal Law 5517/68, in its Article 5, states: "It is the exclusive competence of the veterinarian to perform the following activities and functions at the expense of the Union, the States, the Municipalities, of the Federal Territories, municipal, parastatal and mixed-economy entities and individuals: the practice of clinical veterinary in all its modalities [13]." In addition, the Resolution of the Federal Council of Veterinary Medicine No. 625/95 recognized the dental area as a specialty of the veterinarian [14]. In this line of reflection, Federal Law No. 5081/66, which lays out the practice of the dental surgeon profession, does not refer to clinical and surgical care for nonhuman patients [15].
In parallel to this, Resolution of the Federal Council of Dentistry $179 / 91$, Article 2, states that "Dentistry is a profession that is exercised for the benefit of the health of the human being and of the community, without discrimination in any way or pretext [16]." However, in its entirety, it does not cite permission or prohibition of the dental surgeon's performance in non-human patients, except when referring to the performance with other animals for scientific research purposes. Based on this reading of the legislation, a question was raised about how the teaching of dentistry occurs within undergraduate courses in veterinary medicine in public higher education institutions. According to CIFFONI AND PACHALY (2001) [11], for veterinary doctors: "medical activities related to the oral cavity are generally contemplated in all disciplines of medical training", so the faculty curriculum itself does not contemplate in depth the dental specialties, which is reaffirmed later in the same article: "few undergraduate courses that present the discipline of Veterinary Dentistry formally arranged in the curriculum." Based on this analysis, a survey was made, using data from the Ministry of Education, to better illustrate the reality of Brazil today on this subject.

\section{Comparison between Veterinary and Human Dentistry - Most Common Complications}

To make a comparison between the techniques used in human and veterinary dentistry, recurrent conditions within the veterinary sphere were raised and pathologies that were present only in animals of a single species were excluded from the studies. Periodontal disease is the main oral alteration found in animals of different species [5,7,17-20] and dental fractures, with or without pulp exposure, also make up the most frequent complications $[21,22]$. The treatment of periodontal disease is composed of several steps and is aimed at eliminating its main cause: bacterial plaque [23-25]. The treatment performed by veterinarians follows a protocol composed by removal of calculus, including scaling and root planing, access surgery and extractions in more serious cases, but always with the clarity that the most effective method to maintain oral health is prevention by means of periodic professional prophylaxis associated with daily brushing $[23,24,26]$, corroborating with LINDHE (2010) [24] that the treatment consists of several stages: an initial phase, a corrective phase (when necessary) and a phase with the purpose of monitoring. Elimination or control of biofilm infection and the introduction of cautious plaque control measures result in dental and periodontal health [24]. Dental fractures are part of the veterinarian's routine, $[27,28]$ since animals have a natural exposure to traumatic events and often associate this with potentially harmful masticatory habits - such as biting metal objects [22,29].

In veterinary medicine, when fractured teeth with pulp exposure are treated, endodontic treatment is performed followed by restoration, only in the area related to surgical access, with photopolymerizable resin or amalgam without total reconstruction of the crown. However, when there is space, in order to recover 
function, this procedure is done by means of the cast metal crowns [28]. The choice of endodontic treatment takes into account issues such as pulp vitality, stage of tooth development, previous treatments and severity of periapical lesions. The stages of human and veterinary endodontic treatment follow the same steps: surgical canal access, canal exploration, sequential limb instrumentation and constant irrigation, drying of the conduits, obturation with gutta percha and sealant cements, always performing radiographic monitoring between stages [12,29-31]. It should be emphasized that when the tooth fracture is expressive and there is a need to reproduce a large amount of structure, with the purpose of restoring not only shape but also function, the fabrication of metal prostheses becomes the most indicated, due to its greater resistance and the fact that aesthetic is a secondary concern [28,29]. Dental preparation is done with the objective of avoiding crown movement after cementation, and the use of intraradicular pins with cast metal core or fiberglass pins are indicated in cases where greater retention is required [28].

\section{Results/Discussion}

The literature review was chosen because, according to Fogliatto (2007) [31], it is a modality that brings together ideas from different sources, aiming to construct a new theory or a new form of presentation for an already known subject. The academic work of a university is governed by teaching, research and extension, pillars that strengthen the training of university subjects. As an important part of this training process, integration between departments becomes necessary. However, this movement is not widely promoted, creating an obstacle for the development of multidisciplinary academics, in addition to the standards established as ideals of each profession, making it difficult to create new perspectives with different points of view. This integration action would take more account of the growth and development of animal dentistry. Dentist KEVIN EASLEY reports his experience in a partnership with a veterinarian: during the care, they were able to exchange not only specific information from each area, but also noticed divergent points in their opinions about the same problem, which illustrates the positive effect of the change of perspective because it allows to add to the areas a new look at the existence of the varieties of procedures and techniques to treat the same disease. This exchange of information and knowledge from different areas allows the growth and maturation of a whole system.

A survey was carried out with public higher education institutions that have a course in veterinary medicine in the country. From the perspective of their curricular guidelines and analysis of their disciplinary grades, it was observed which offer the discipline of dentistry as compulsory or optional (Table 1). From the analysis of this graph, it is possible to perceive that $0 \%$ of the veterinary courses currently in public institutions in the country have the discipline of dentistry as a compulsory part of the curriculum and approximately $8 \%$ offer the subject as optional, therefore the percentage of students who have the opportunity to attend the discipline is greatly reduced. With restrictive regulations from the council of veterinary medicine, dentists are prevented from providing this service and courses in veterinary medicine do not provide sufficient manpower to supply the existing demand, which may impact on the quality of dental veterinary service and animals' quality of life. Contrary to CIFFONI and PACHALY (2001) [11], when said that there is no technical skill on the part of dental surgeons, it was demonstrated in this review that the protocol of dental care performed by veterinarians is, in its macrostructure, similar to the one realized in humans since the dentistry practiced in the veterinary scope derives from the human dentistry.

Table 1: Of the 264 universities in Brazil, 260 had data available on the internet for analysis, and of these only 48 offered the veterinary course. Of the 48 , only 4 offer the subject of dentistry as an optional subject in its curriculum.

\begin{tabular}{|c|c|c|}
\hline Veterinary courses & Dentistry (optional) & Dentistry (required) \\
\hline 48 & $4(8,33 \%)$ & $0(0 \%)$ \\
\hline
\end{tabular}

Constant clinical and laboratory research conducted by dental surgeons on dental applications as a whole is a reality and could contribute to and enhance animal dentistry due to the proximity of this relationship. It becomes evident despite the similarity of treatments the need for a specialization in veterinary dentistry regardless of the professional who performs the procedures, since as veterinarians need to deepen their knowledge about dental specialties, the dental surgeon also needs of learning about the macro and micropeculiarities of each species. This exclusivist care, backed by a teaching in which the exchange of knowledge between departments is not something present, could be minimized by offering courses in veterinary dentistry, which allows the registration of other areas provided they met basic prerequisites, contributing to the beginning of a multidisciplinary process. In view of the above, it can be stated that the protocol of veterinary care on the mentioned diseases is, in terms of technical ability, very similar, if not identical, to what one learns in the courses of human dentistry, thus proving that the dental surgeon is able to perform the procedures in order to contemplate the demand of veterinary dentistry, as long as they have knowledge on the anatomical characteristics of each species.

It is possible to observe from the analysis of the current legislation that there is no legal restriction on the practice of the dental surgeon's profession regarding the care of non-human patients; on the other hand, there is an explicit prohibition of the performance of other professionals by the legislation that regulates the performance of the veterinarian. It is important, therefore, to revisit the regulatory framework on the two areas of action, specifically veterinary medicine, since there is a need for new paradigms that aim to qualify the offer of services and, in turn, human dentistry, which is an area of constant technical and scientific growth, could add positively to the veterinary scope. The 
main character of a law is to be at the service of the social good. Thus, it must have the predictability of changes when observed the movements of paradigmatic and cultural changes of a society. The analysis of the regulatory frameworks in force in Brazil today showed legislation that did not follow the advances and changes demanded for the courses of veterinary medicine and dentistry, regarding the possibilities of integration between the areas, nor a concern to take the discussion to the scope of the academic society.

As presented throughout the work, there is competence for the dental surgeon to provide the service and the veterinarian could have his or hers ability refined as long as a dialogue with dentistry is present. However, the dentist needs legal support for an in-depth exchange in which all dental specialties can be studied and performed in order to improve the quality of care. This review sought to show the need to review the courses of veterinary medicine offered in the country, as well as the laws that govern the practice in veterinary dentistry. The debate about the possibility of service should be based on the quality provided and not on market restriction, just as the collective must come before individual ambitions or corporate interests. The interdisciplinary care is beneficial for all involved and the questioning about the cultural dogmas of each profession that exist exclusively in its scope of action should be stimulated, therefore, however antagonistic it might seem at first sight, all specific peculiarities are complementary. We need to dialogue, argue and learn more with each other.

\section{Conclusion}

This paper does not pretend to exhaust the theme, but to contribute to the reflection around the presented question. From this, it is concluded that the joint action between veterinarians and dental surgeons, both specialized in veterinary dentistry, is a sine qua non for an improvement in the quality of care provided and, consequently, an improvement in the animal's quality of life and the reformulation of the curriculum of both courses is the beginning for this interdisciplinary action.

\section{References}

1. Kevin Easley (1999) Veterinary Dentistry: Its Origin and Recent History. Journal of the History of Dentistry 47(2): 83-85.

2. Venturini MAFA (2006) Estudo retrospectivo de 3055 animais atendidos no ODONTOVET $®$ (Centro Odontológico Veterinário) durante 44 meses. Dissertação de Mestrado em Medicina Veterinária Faculdade de Medicina Veterinarians e Zootecnia, Universidade de São Paulo, USP.

3. Fecchio RS, Prazeres RF, Rossi Jr JL, GIOSO MA (2010) Prevalência de lesões orais em primatas atendidos na casuística do Laboratório de Odontologia Comparada (LOC FMVZ-USP) entre os anos de 1999 e 2010. Nosso Clínico 13: 54-55.

4. Praters RF (2014) Araliaceous das afecções odontológicas em pequenos felídeos neotropicais mantidos em cativeiro. Dissertação (Mestrado em Ciências)-Faculdade de Medicina Veterinária e Zootecnia, Universidade de São Paulo, USP.

5. Fugita MS (2016) Estudo retrospectivo das afecções orais em 754 Felinos domésticos (Felis catus) atendidos no Laboratório de Odontologia Comparada da Universidade de São Paulo. Dissertação de Mestrado em Ciências-Faculdade de Medicina Veterinária e Zootecnia, Universidade de São Paulo, USP.
6. Gioso MA, Silva JCR, Rossi JL, Marvulo MFV (2000) Prevalência de fraturas dentais em Onça Pintada (panthera onca) e Suçuarana (puma concolor) mantidas em cativeiro no estado de São Paulo. Anais do I V Congresso e I X Encontro da ABRAVAS , São Pedro/SP.

7. Dias Neto RN (2014) Achados clínicos de afecções orais em Bugios Ruivos (Alouatta guariba clamitans). Dissertação de Mestrado-Faculdade de Medicina Veterinária e Zootecnia, Campus de Botucatu, Universidade Estadual Paulista, UNESP

8. Pachaly JR (2006) Odontoestomatologia, In: Cubas ZS, Silva JCR, CatãoDias JL, Tratado de Animais Selvagens. (1를. Edn.). São Paulo: Roca pp. 1068-1091.

9. Harvey CE (1994) The history of veterinary dentistry part one: from the earliest record to the end of the 18th century. Journal of Veternary Dentistry 11(4): 135-139.

10. Silva RHA (2005) Atividade Ilícita Profissional em Odontologia: Análise do conhecimento de acadêmicos, magistrados e entidades promotoras de curso de aperfeiçoamento e/ou especialização, no município de Bauru-SP. Dissertação de Mestrado-Faculdade de Odontologia de Bauru, Universidade de São Paulo, USP.

11. Ciffoni EMG, Pachaly JR (2001) Considerações históricas e legais sobre a odontologia veterinária no Brasil. Arq Ciência Veterinária e Zoologia, UNIPAR 4(1): 49-54.

12. Gioso MA (2007) Odontologia Veterinária para o Clínico de Pequenos Animais. Edição. São Paulo 2.

13. (1968) Brasil. Lei no 5.517.

14. (1995) Brasil. Resolução no 625.

15. (1966) Brasil. Lei oㅜ 5.081.

16. (1991) Brasil. Resolução no 179.

17. Lino AJB, Rossi Junior JL, Rangel MCV (2014) Levantamento da incidência de doença periodontal em cães (Canis familiaris) avaliados durante campanha de castração em Santa Teresa e Guarapari-ES. Nosso Clínico 101: 44-48.

18. Rossi Jr JL, Gioso MA, Falqueiro LMD (2007) Estudo comparativo sobre prevalência de doença periodontal em Panthera onca mantida em cativeiro e em indivíduos natureza Pesq. Vet Bras 27(5): 209-214.

19. Fecchio RS (2005) Prevalência de lesões orais em Macacos prego (Cebus apella) mantidos em cativeiro no estado de São Paulo. Monografia de conclusão de curso, Faculdade de Medicina Veterinária da Universidade Metodista de São Paulo.

20. Fecchio RS, Petri BSS, Zanco NA, Gioso MA (2009) Prevalência de afecções orais em cães na casuística cirúrgica do Hospital Veterinário da Universidade Metodista de São Paulo. Revista CFMV-Brasília/DF-Ano 15: 48 .

21. Furtado MM, Kashivakura CK, Ferro C, Jácomo ATA, Silveira L, et al. (2007) Prevalence of crown trauma in free-ranging maned wolves (Chrysocyon brachyurus) in Central Brazil. J Vet Dent 24(4): 231-234.

22. Santos NS, Carlos RSA, Albuquerque GR (2012) Doença periodontal em cães e gatos-revisão de literatura. Medvep-Revista Cientifica de Medicina Veterinária-Pequenos Animais e Animais de Estimação 10: 1-637.

23. Pires BC, Waki MF, Correa HL, Ferro DG, Venturini MAFA, et al. (2013) Doença periodontal: fisiopatogenia e tratamento (relato de caso e revisão). Nosso Clínico 96: 6-10.

24. Lindhe J Lang, N Karring (2010) Tratado de periodontia clínica e implantodontia oral, (5ª edn.). Rio de Janeiro pp. 629-647.

25. Miranda RA (2004) Abordagem clínicae cirúrgica da doença periodontal. Monografia curso de atualização em odontologia de pequenos animais, ANCLIVEPA-SP, São Paulo.

26. Ferreira J, Ferro DG, PIRES BC, Venturini MAFA, Correa HL, et al. (2015) Iatrogenia em endodontia veterinária (relato de dois casos). Nosso Clínico 18: 108. 
27. Camargo SLS, Gil C, Campos TN, Contin I, Mori M, et al. (2012) Retentores intrarradiculares metálicos na reconstrução coronal com restauração metálica fundida (RMF) em cães-revisão de literatura. Clínica veterinária Ano 17: 97

28. Fink L, Reiter AM (2015) Assessment of 68 Prosthodontic Crowns in 41 Pet and Working Dogs (2000-2012). J VET DENT 32(3): 148-154.

29. Lopes HP, Siqueira Jr JF (2010) Endodontia biologia e técnica, ( $3^{\mathrm{a}}$ edn.). Rio de Janeiro.

\section{ISSN: 2574-1241}

DOI: 10.26717/BJSTR.2019.16.002825

Déborah Lousan do Nascimento P. Biomed J Sci \& Tech Res

(C) This work is licensed under Creative

Submission Link: https://biomedres.us/submit-manuscript.php
30. Souza RA, Gavazza F, Dantas JCP, Lago M, Colombo S (2016) Tratamento endodôntico de incisivo lateral superior com curvatura apical acentuada e lesão periapical-relato de caso. Revista Bahiana de Odontologia. 7(1): 74-79.

31. Leon Bornan MA, Gioso MA (2004) Endodontia-anatomia, fisiopatologia e terapia para afecções dos tecidos internos do dente. MEDVEP Revista Cientifica de Medicina Veterinária-Pequenos Animais e Animais de Estimação 2: 195-203.

$\begin{array}{ll}\text { BIOMEDICAL } & \text { Assets of Publishing with us } \\ \text { RESEARCHES } & \text { - Global archiving of articles } \\ & \text { - Immediate, unrestricted online access } \\ & \text { - Rigorous Peer Review Process } \\ \end{array}$

